\title{
Lactic Acid Fermentation: Preparation and Evaluation of Lactic Acid Fermented Carrot Appetizer
}

\section{Sarita Devi and VK Joshi*}

Department of Food Science and Technology, Dr Y S Parmar University of

Horticulture and Forestry, India

*Corresponding Author: VK Joshi, Department of Food Science and Technology,

Dr Y S Parmar University of Horticulture and Forestry, India.
Received: December 09, 2020

Published: March 11, 2021

(C) All rights are reserved by Sarita Devi and

VK Joshi.

\section{Abstract}

Lactic acid fermented carrot appetizer with various pulp content was prepared and was further evaluated for various physicochemical and sensory characteristics. With a decrease in fermented pulp concentration there was an increase in reducing sugars, total sugars and $\mathrm{pH}$ while salt, titrable acidity, vitamin C, carotene content and colour decreased. Due to low salt concentration, fermentable pulp was found to be more suitable for the preparation of appetizer than other products. The optimized lactic fermented appetizer had $50 \%$ fermented pulp and $50 \%$ unfermented pulp as per the standard recipe. Vitamin C content ranged between 12.00 to $28.10 \mathrm{mg} / 100 \mathrm{~g}$. In case of carrot appetizer, treatment with $50 \%$ fermented pulp $+50 \%$ unfermented pulp gave the best results for physico-chemical as well as sensory characteristics. Physico-chemical characteristics were in the range of prescribed specifications. During the passage of storage period of the appetizer for six months, there was no drastic change but only slight changes in all the physico-chemical and sensory characteristics except $\mathrm{pH}$, reducing sugars and browning where significant changes took place. Overall, the changes during storage did not affect the acceptability of the product to a greater extent.

Keywords: Lactic Acid Fermentation; Appetizer; Carrot; Storage

\section{Introduction}

Carrot (Daucus carota L) belongs to family umbelliferae and is one of the most important vegetable among the root vegetables and is taken raw as salad or cooked as vegetable or used in the preparation of sweet dishes like Gazar ka Halwa. It is a good source of carbohydrates thiamin, riboflavin, niacin, vitamin $\mathrm{C}$, folic acid, carotene and minerals [1,2]. It acts as anti-aneamic, diuretic, remineralising with healing and sedative properties $[3,4]$. The abundant production of these vegetables during the season, results in a glut in the market. Consequently, a large quantity of these vegetables gets spoiled. Preservation of these perishables in one or the other form is a suitable tool to save the wastage of vegetables besides making them available in off-season. Fermentation is one of the methods to preserve these vegetables [5].

China is believed to be the birth place of the process of fermented vegetables, the preservation by fermentation began before the recorded history [2]. Fermentation using natural or starter culture has emerged to be a cheap method of preservation. Lactic acid fermentation is a potent tool for bio-preservation and product development $[6,7]$. Studies on various aspect of lactic acid fermentation of vegetables have been reported [8-12]. It is carried out by lactic acid bacteria which also play a significant role as probiotic foods besides producing a number of antimicrobial compounds like bacteriocin, reutrin etc. $[13,14]$. The effect of different additives on the 
lactic acid fermentation of radish that the acid production pattern in sequential lactic acid fermentation of radish is influenced by the addition of additives [15]. Most of the fermented vegetables are not consumed as such but converted into products and thus, preparation of new products with diversified taste and flavor is desirable. to provide variety to the diet in the form of diversified products. The lactic acid fermented foods include fermented grape juice, fermented peanut milk, sogurt, fermented corn meal, kuhanzaki and fermented beverages from wheat and maize [5]. The most recent application of lactic acid fermented vegetables has been made in the production of value added products viz., sauce, RTS, appetizers, instant chutney mix vegetable juices etc. [16-20]. Such products have also received encouraging interest due to their therapeutic values. But the available technology also needs to be refined so that the same is absorbed by the industry. Keeping these in view, evaluation of lactic acid fermentation as a potential process for making new products from carrot viz; appetizer was undertaken and reported here.

\section{Material and Methods \\ Raw materials}

Carrots of optimum maturity and other ingredients like salt, sugar and spices were procured locally.

\section{Lactic acid fermentation of carrot}

Carrots of optimum maturity were washed, peeled and grated. The grated pieces had length of $1.5 \mathrm{~cm}$ and $2 \mathrm{~mm}$ thickness. The slices were fermented using optimized salt concentration of $2.5 \%$ and mustard $2 \%$ [7]. Fermentation was carried out by natural micro flora as per the procedure adopted for sauerkraut preparation. During fermentation, rate of fermentation, $\mathrm{pH}$ and titrable acidity and micro-flora were recorded. On completion of fermentation i.e. when further increase in acidity did not take place, the fermented vegetable was converted into pulp.

Carrot paste/pulp was made by addition of water in 1:1 ratio to the respective fermented vegetable in a mixer which was kept in sterilized glass jars by adding potassium metabisulphite $(1500$ ppm) for later use in the product development viz. Fermented carrot appetizer by blending with unfermented carrot pulp in different proportions [20].
Preparation of carrot appetizer

\begin{tabular}{|l|c|c|}
\hline \multicolumn{1}{|c|}{ Treatments } & \multicolumn{1}{|c|}{$\begin{array}{c}\text { Fermented } \\
\text { carrot pulp (per } \\
\text { cent) }\end{array}$} & $\begin{array}{c}\text { Unfermented } \\
\text { carrot pulp } \\
\text { (per cent) }\end{array}$ \\
\hline $\mathrm{T}_{1}$ (fermented carrot) & 100 & - \\
\hline $\begin{array}{l}\mathrm{T}_{2} \text { (fermented carrot }+ \\
\text { unfermented carrot) }\end{array}$ & 60 & 40 \\
\hline $\begin{array}{l}\mathrm{T}_{3} \text { (fermented carrot }+ \\
\text { unfermented carrot) }\end{array}$ & 55 & 50 \\
\hline $\begin{array}{l}\mathrm{T}_{4} \text { (fermented carrot }+ \\
\text { unfermented carrot) }\end{array}$ & 50 & 55 \\
\hline $\begin{array}{l}\mathrm{T}_{5} \text { (fermented carrot }+ \\
\text { unfermented carrot) }\end{array}$ & 45 & 60 \\
\hline $\begin{array}{l}\mathrm{T}_{6} \text { (fermented carrot }+ \\
\text { unfermented carrot) }\end{array}$ & 40 & \\
\hline
\end{tabular}

Table 1: Details of treatments used for the preparation of appetizer from carrot.

Sugar syrup was prepared separately, strained through a muslin cloth, cooled and added to the calculated quantity of pulp/paste. The pulp/paste of respective fermented carrot as well as unfermented carrot were mixed in different proportions (Table 1). and used to prepare appetizer. The final TSS of all the appetizers were kept at $42^{\circ} \mathrm{B}$. Pre-determined quantity of spices (cardamom, dry ginger, cumin, black pepper and salt) as per the standard recipe given in table 2 , were boiled in $200 \mathrm{ml}$ water, strained through a muslin cloth and added to the mixture of pulps and sugar syrup. The mint and ginger extracts were added as per the standard recipe (Table 2). Potassium metabisulphite @ 700ppm was added to the product and mixed well. The prepared appetizers of various treatments were filled in the pre-cleaned, sterilized, dried bottles(coloured bottles) of $650 \mathrm{ml}$ capacity, crown corked, labelled and analyzed for various characteristics.

\section{Analyses}

\section{Physico-Chemical characteristics}

Total soluble solids (TSS) were measured using Erma hand refractometer $\left(0-32^{\circ} \mathrm{B}, 28-60^{\circ} \mathrm{B}\right)$. The results were expressed as degree Brix $\left({ }^{0} \mathrm{~B}\right)$. The readings were corrected by applying correction 


\begin{tabular}{|l|c|}
\hline \multicolumn{1}{|c|}{ Ingredients } & Quantity \\
\hline Vegetable pulp(g) & 1000 \\
\hline Sugars(g) & 1600 \\
\hline Water(ml) & 500 \\
\hline Salt(g) & 25 \\
\hline Citric acid(g) & 10 \\
\hline Dry ginger(g) & 4 \\
\hline Cardamom(g) & 4 \\
\hline Cumin(g) & 10 \\
\hline Black pepper(g) & 10 \\
\hline KMS(g) & 2 \\
\hline
\end{tabular}

Table 2: Details of ingredients used for the preparation of appetizers.

factor for the temperature variation, wherever needed [21]. The $\mathrm{pH}$ was taken with HPG, G-2004 pH meter, after calibrating it with buffer solutions of $\mathrm{pH} 4$ and 9.2 [22]. The measured sample of $10 \mathrm{~g}$ was grounded and the juice was filtered prior to $\mathrm{pH}$ recording.

Titratable acidity was estimated by treating a known aliquot of the sample against $\mathrm{N} / 10 \mathrm{NaOH}$ solution using phenolphthalein as an indicator. The titratable acidity was calculated and expressed as per cent lactic acid [21]. Reducing sugar contents were estimated by Lane and Eynon's volumetric method [21] by titrating the prepared sample against a known quantity of Fehling's solution to a brick red precipitates as the end point using methylene blue as indicator. The results were expressed as percent reducing sugar content. The total sugar contents of fruits were also estimated by Lane and Eynon's volumetric method [21] by titrating the prepared sample after hydrolysis with concentrated hydrochloric acid similar to reducing sugar and expressed as:

$\%$ Total sugars $=(\%$ reducing sugars $+\%$ sucrose $)$

Salt in the sample was determined by the titration method and was calculated and expressed as per cent sodium chloride as per the method described [21]. Ascorbic acid content of various samples of product was determined as per standard method [21] using 2,6-dichlorophenol-indophenol dye. The sample was extracted in 3 per cent metaphosphoric acid solution and titrated with the dye to pink end point. The results were expressed as $\mathrm{mg} / 100 \mathrm{~g}$ of sam-
ple.In carrot products, carotene was estimated according to the method described [22] and expressed as mg/100g. Non-enzymatic browning was determined as per the method of A.O.A.C. method [21]. Absorbance of filtrate was recorded at $440 \mathrm{~nm}$ using $60 \%$ alcohol as blank in a spectrophotometer and expressed as optical density (OD).

\section{Sensory evaluation}

The sensory evaluation of carrot based appetizer was conducted by semi-trained panel of 10 judges. Each judge was given a set of products separately in isolated booth and provided with a glass of fresh water to rinse their mouth before tasting the next sample. Each sample was evaluated for various quality attributes viz. colour, consistency/texture, aroma, taste/acid sugar blend, overall acceptability. The judges were asked to rate the samples on a prescribed sensory evaluation Performa. The evaluation was done on a 9 point Hedonic scale. Respective appetizers were diluted in 1:3 ratios and then, served to the judges. The procedure followed was the same as described earlier [23].

\section{Statistical analysis}

The data of quantitative estimation of various physico-chemical characteristics of different fermented products were anlaysed by Completely Randomized Design (CRD) while the data of sensory evaluation were analysed by Randomized Block Designs (RBD) as described by O’Mahony [24].

\section{Results and Discussion}

Optimization of carrot appetizer preparation

Physico-chemical characteristics

The total soluble solids $\left(42^{\circ} \mathrm{B}\right)$ were the same in all the treatments (Table 3). For products like squash and appetizer, the minimum TSS prescribed is $40^{\circ} \mathrm{B}$. The total soluble solids content of carrot based appetizer were not expected to be different as the same was fixed in the recipe as per the specifications [25]. The $\mathrm{pH}$ values of appetizers of different treatments ranged from 2.52 to 2.85. The highest (2.85) and lowest (2.52) $\mathrm{pH}$ were recorded in $\mathrm{T}_{6}$ ( $40 \%$ fermented carrot pulp $+60 \%$ unfermented carrot pulp) and $\mathrm{T}_{1}(100 \%$ fermented carrot pulp), respectively. The titrable acidity ranged between 1.28 and 1.70 per cent (lactic acid). The highest $(1.70 \%)$ and lowest (01.28\%) titrable acidity was observed in $\mathrm{T}_{1}$ (100\% fermented carrot pulp) carrot appetizer which was statistically at par with $\mathrm{T}_{2}$ and lowest $3.04 \%$ in $\mathrm{T}_{6}(40 \%$ fermented carrot 


\begin{tabular}{|l|c|l|c|c|c|c|c|c|c|}
\hline Treatment & $\begin{array}{c}\text { TSS } \\
\mathbf{(} \mathbf{B})\end{array}$ & $\mathbf{p H}$ & $\begin{array}{c}\text { Reducing } \\
\text { Sugars } \\
\mathbf{( \% )}\end{array}$ & $\begin{array}{c}\text { Total } \\
\text { Sugars } \\
\mathbf{( \% )}\end{array}$ & $\begin{array}{c}\text { Salts } \\
\mathbf{( \% )}\end{array}$ & $\begin{array}{c}\text { Titrable } \\
\text { acidity } \\
\mathbf{( \% ~ C A ) ~}\end{array}$ & $\begin{array}{c}\text { Vit C } \\
(\mathbf{m g} / \mathbf{1 0 0 g})\end{array}$ & $\begin{array}{c}\text { Carotene } \\
(\mathbf{m g} / \mathbf{1 0 0 g})\end{array}$ & $\begin{array}{c}\text { Colour (OD } \\
\mathbf{4 4 0} \mathbf{~ n m})\end{array}$ \\
\hline T1 & 42.00 & 2.52 & 5.26 & 37.31 & 3.22 & 1.70 & 28.10 & 4.78 & 0.03 \\
\hline T2 & 42.00 & 2.57 & 5.35 & 37.69 & 3.18 & 1.66 & 24.00 & 4.65 & 0.04 \\
\hline T3 & 42.00 & 2.61 & 5.42 & 38.46 & 3.15 & 1.57 & 20.20 & 4.12 & 0.03 \\
\hline T4 & 42.00 & 2.63 & 5.50 & 39.68 & 3.08 & 1.53 & 16.12 & 4.03 & 0.03 \\
\hline T5 & 42.00 & 2.65 & 5.62 & 41.66 & 3.05 & 1.46 & 14.40 & 3.34 & 0.03 \\
\hline T6 & 42.00 & 2.85 & 5.83 & 41.70 & 3.04 & 1.28 & 12.00 & 2.59 & 0.03 \\
\hline CD $(\geq 0.05)$ & NS & 0.05 & 0.06 & 0.06 & 0.06 & 0.05 & 0.06 & 0.06 & NS \\
\hline
\end{tabular}

Table 3: Physico-chemical characteristics of carrot based appetizer.

pulp $+60 \%$ unfermented carrot pulp. The higher titratable acidity observed in $\mathrm{T}_{1}(100 \%$ fermented carrot pulp) is consistent with its high initial value in fermented carrot pulp. Reverse is the reason for lower titratable acidity. The titrable acidity in other products where different proportions of unfermented carrot pulp was blended was not fixed but it was kept in accordance with TSS so that a palatable acid/sugar blend is achieved. The highest $\mathrm{pH}$ (2.85) was recorded in product $\mathrm{T}_{6}$ (40\% fermented carrot pulp+ $60 \%$ unfermented carrot pulp) and lowest (2.52) in $\mathrm{T}_{1}(100 \%$ fermented carrot pulp) which was statistically at par with $\mathrm{T}_{2}$. The results of $\mathrm{pH}$ value are in consistence with the earlier result of titratable acidity.

The reducing sugar content of appetizers of various treatments ranged from 5.26 to 5.83 per cent. The highest reducing sugars i.e. $5.83 \%$ were recorded in $\mathrm{T}_{6}(40 \%$ fermented carrot pulp $+60 \%$ unfermented carrot pulp and lowest (5.26\%) in $\mathrm{T}_{1}$ (100\% fermented carrot pulp), respectively. The results clearly show that there were significant differences with respect to total sugars among the various treatments which ranged between 37.31 to 41.70 per cent. The highest (41.70\%) total sugar was recorded in $\mathrm{T}_{6}$ (40\% fermented carrot pulp $+60 \%$ unfermented carrot pulp) carrot appetizer which was statistically at par with $\mathrm{T}_{4}$ and $\mathrm{T}_{5}$ whereas lowest 37.21 per cent in $\mathrm{T}_{1}(100 \%)$ was found in fermented carrot pulp.

There was a significant difference with respect to salts content among the various treatments. The highest (3.22\%) was recorded in $\mathrm{T}_{1}(100 \%$ fermented carrot pulp) carrot appetizer and lowest $3.04 \%$ in $\mathrm{T}_{6}$ (40\% fermented carrot pulp+ $60 \%$ unfermented carrot pulp). The higher salts (3.22) recorded in product $\mathrm{T}_{1}(100 \%$ fermented carrot pulp) which was statistically at par with $\mathrm{T}_{2}$ and minimum (3.04) was in $\mathrm{T}_{6}(40 \%$ fermented carrot pulp $+60 \%$ un- fermented carrot pulp) which was statistically at par with $\mathrm{T}_{4}$ and $\mathrm{T}_{4}$. There is no limit for the salt concentration in the appetizer but its contents are added so as to impart the salty taste to the product, being an appetizer.

There were significant differences with respect to vitamin $\mathrm{C}$ among the various treatments (Table 3). It ranged between 12.00 to $28.10 \mathrm{mg} / 100 \mathrm{~g}$. The highest $(28.10 \mathrm{mg} / 100 \mathrm{~g})$ was recorded in $\mathrm{T}_{1}(100 \%$ fermented carrot pulp) RTS drink and lowest 12.00 $\mathrm{mg} / 100 \mathrm{~g}$ in $\mathrm{T}_{6}(40 \%$ fermented carrot pulp $+60 \%$ unfermented carrot pulp). Vitamin $\mathrm{C}$ content recorded in $\mathrm{T}_{1}(100 \%$ carrot pulp) is consistent with their higher initial values in the fermented carrot pulp. Reverse could be the reason for lower vitamin $\mathrm{C}$ in $\mathrm{T}_{6}(40 \%$ fermented caarot pulp $+60 \%$ unfermented carrot pulp).

There were significant differences with respect to carotene content among the various treatments (Table 3 ). These ranged between 2.59 to $4.78 \mathrm{mg} / 100 \mathrm{~g}$. The highest (4.78\%) was recorded in $\mathrm{T}_{6}$ ( $40 \%$ fermented carrot pulp+ $60 \%$ unfermented carrot pulp) carrot appetizer and lowest $2.59 \mathrm{mg} / 100 \mathrm{~g}$ in $\mathrm{T}_{1}(100 \%$ fermented carrot pulp). As far as colour of appetizer was concerned, there were non - significant differences with respect to colour (browning) among the various treatments. The higher carotene recorded in $\mathrm{T}_{6}$ (40\% fermented carrot pulp+ $60 \%$ unfermented carrot pulp) are consistent with their higher initial values in the unfermented carrot pulp. Reverse could be the reason for lower carotene content in $\mathrm{T}_{1}(100 \%$ carrot pulp).

An appraisal of the various parameters of analysis with FSSAI revealed that all the physico-chemical characteristics are within the limits prescribed for the appetizers [26]. 


\section{Sensory characteristics of carrot appetizer}

The colour scores with respect to fermented carrot based appetizers of different treatments ranged from 7.20 to 8.09 (Table 4).Maximum score (8.09) was recorded in $\mathrm{T}_{1}(100 \%$ fermented carrot pulp) fermented carrot based appetizer, which was at par with $\mathrm{T}_{2}$ (60\% fermented carrot pulp $+40 \%$ unfermented carrot pulp). However, minimum colour score (7.20) was awarded to $\mathrm{T}_{6}(40 \%$ fermented carrot pulp $+60 \%$ unfermented carrot pulp). Higher colour scores of $\mathrm{T}_{1}$ and $\mathrm{T}_{2}$ hold promise for preparation of fermented appetizer of high acceptability.

The flavour scores of different appetizer varied from 6.70 to 7.88 (Table 4). The highest flavour score (7.88) was recorded in $\mathrm{T}_{4}$ (50\% fermented carrot pulp $+50 \%$ unfermented carrot pulp) which was at par with $\mathrm{T}_{5}$ whereas, the lowest score (6.70) was recorded in $\mathrm{T}_{3}$ (55\% fermented carrot pulp $+45 \%$ unfermented carrot pulp) which was at par with $\mathrm{T}_{2}(60 \%$ fermented carrot pulp + $40 \%$ unfermented carrot pulp). Hence, $\mathrm{T}_{4}$ was adjudged the most liked treatment with respect to flavour attribute.

\begin{tabular}{|l|c|c|c|c|c|}
\hline Treatment & Colour & Flavour & Body & Taste & $\begin{array}{c}\text { Overall } \\
\text { acceptability }\end{array}$ \\
\hline T1 & 8.09 & 7.61 & 7.35 & 7.70 & 7.43 \\
\hline T2 & 7.88 & 6.92 & 7.46 & 6.90 & 6.62 \\
\hline T3 & 7.50 & 6.70 & 7.40 & 6.80 & 6.60 \\
\hline T4 & 7.40 & 7.88 & 8.20 & 8.40 & 8.35 \\
\hline T5 & 7.30 & 7.70 & 7.50 & 7.31 & 7.20 \\
\hline T6 & 7.20 & 7.30 & 7.20 & 6.64 & 7.40 \\
\hline CD $_{(20.05)}$ & 0.28 & 0.26 & 0.23 & 0.23 & 0.21 \\
\hline
\end{tabular}

Table 4: Sensory evaluation of appetizers prepared from fermented carrot.

**Sensory evaluation on Hedonic scale Maximum score of 9.00.

Highest score (8.20) for body was awarded to $\mathrm{T}_{4}(50 \%$ fermented carrot pulp $+50 \%$ unfermented carrot pulp) while the lowest score (7.20) was recorded in $\mathrm{T}_{6}$ ( $40 \%$ fermented carrot pulp $+60 \%$ unfermented carrot pulp) The taste scores of different fermented carrot based appetizer varied from 6.64 to 8.40 . The highest taste score (8.40) was recorded in $\mathrm{T}_{4}$ (50\% fermented carrot pulp $+50 \%$ unfermented carrot pulp) while the lowest was found in $\mathrm{T}_{6}(40 \%$ fermented carrot pulp $+60 \%$ unfermented carrot pulp) fermented carrot based appetizer, though at par with $\mathrm{T}_{3}(55 \%$ fermented carrot pulp $+45 \%$ unfermented carrot pulp). Hence, treatment $\mathrm{T}_{4}$ was the most liked for taste attribute and was adjudged as the best product. Better sugar-acid blend of this treatment must have imparted an acceptable taste to $\mathrm{T}_{4}$ treatment.

A perusal of the data tabulated in Table 4 revealed that overall acceptability score of different fermented carrot based appetizers, these ranged between 6.60 to 8.40 . The highest score (8.40) was recorded in $\mathrm{T}_{4}(50 \%$ fermented carrot pulp $+50 \%$ unfermented carrot pulp) and the least liked treatment $\mathrm{T}_{3}(55 \%$ fermented carrot pulp $+45 \%$ unfermented carrot pulp). Based on the sensory evaluation scores of different attributes, $\mathrm{T}_{4}(50 \%$ fermented carrot pulp $+50 \%$ unfermented carrot pulp) ranked as the best and was considered as the the most suitable blend for making fermented appetizer making.

In consistence with the trend of various attributes discussed, the overall acceptability score of $\mathrm{T}_{4}(50 \%$ fermented carrot pulp + $50 \%$ unfermented carrot pulp) confirms the suitability of fermented carrot based appetizer. Similar, findings have also been reported by Joshi., et al. [18] that the physico-chemical and sensory characteristics of all appetizer prepared from fermented vegetables met the FASSI specifications [26].

\section{Effect of storage temperature and interval}

The data (5 and 6) revealed that there were statistically nonsignificant differences among the storage conditions as well as interaction between the storage conditions and storage intervals with respect to $\mathrm{pH}$ and acidity. Initial $\mathrm{pH}$ was 2.63 which increased to 2.67 and 2.69 after 6 months under ambient temperature and refrigerated temperature, respectively.

Corroborating with $\mathrm{pH}$, titrable acidity decreased from $1.53 \%$ to $1.02 \%$ under ambient conditions and from $1.5 \%$ to $1.031 \%$ under refrigerated conditions (Table 5). Maximum salt content was estimated on 0 month as $3.08 \%$ whereas lowest was observed at 
$3.00 \%$ at ambient temperature after 6 month of storage. Statistically, similar results have been obtained in for total soluble solids, reducing sugars and total sugar (5 and 6). There was a decrease in TSS during storage interval. It reduced from $42^{\circ} \mathrm{B}$ to $41.6^{\circ} \mathrm{B}$ followed by $41.2^{\circ} \mathrm{B}$. Reducing sugar also decreased during storage conditions though the decrease in absolute terms was very minor.. After 3 months its decline was from $5.5 \%$ to $5.39 \%$ and finally to $5.26 \%$ at ambient temperature whereas under refrigerated condition it ranged $5.5 \%$ to $5.2 \%$. Total sugar content increased dur-
Table 7 depicts the effect of storage conditions and storage time on vit $\mathrm{C}$ content, carotene content as well as browning of carrot based appetizer, respectively. Both vitamin $\mathrm{C}$ content and carotene content decreased during storage both at ambient and refrigerated temperature whereas there was a slight increase in browning content during storage interval. Statistically, it is evident that there are significant difference in treatments for storage condition in case of vit $\mathrm{C}$ and browning whereas non-significant in case of carotene.

\begin{tabular}{|c|c|c|c|c|c|c|c|c|c|}
\hline \multirow{2}{*}{$\begin{array}{c}\text { Storage } \\
\text { intervals (I) } \\
\text { Months }\end{array}$} & Storage c & $\begin{array}{l}\text { pH } \\
\text { ondition }\left({ }^{\circ} \mathrm{C}\right)\end{array}$ & \multirow[t]{2}{*}{ Mean } & \multicolumn{2}{|c|}{$\begin{array}{c}\text { Titrable acidity } \\
\text { Storage condition }\left({ }^{\circ} \mathrm{C}\right)\end{array}$} & \multirow[t]{2}{*}{ Mean } & \multicolumn{2}{|c|}{$\begin{array}{c}\text { Salt (\%) } \\
\text { Storage condition }\left({ }^{\circ} \mathrm{C}\right)\end{array}$} & \multirow[t]{2}{*}{ Mean } \\
\hline & Ambient & Refrigerated & & Ambient & Refrigerated & & Ambient & Refrigerated & \\
\hline 0 & 2.630 & 2.630 & 2.630 & 1.530 & 1.530 & 1.530 & 3.080 & 3.080 & 3.080 \\
\hline 3 & 2.630 & 2.650 & 2.630 & 1.400 & 1.440 & 1.420 & 3.040 & 3.060 & 3.050 \\
\hline 6 & 2.670 & 2.690 & 2.640 & 1.024 & 1.031 & 1.028 & 3.000 & 3.020 & 3.010 \\
\hline Mean & 2.643 & 2.657 & & 1.318 & 1.334 & & 3.040 & 3.053 & \\
\hline
\end{tabular}

Table 5: Effect of storage temperature and interval on $\mathrm{pH}$, titrable acidity and of fermented carrot appetizer.

\begin{tabular}{|c|c|c|c|c|c|c|c|c|c|}
\hline $\begin{array}{c}\text { Storage } \\
\text { intervals } \\
\text { (I) } \\
\text { Months }\end{array}$ & \multicolumn{2}{|c|}{$\begin{array}{c}\operatorname{TSS}\left({ }^{0} \mathrm{~B}\right) \\
\text { Storage condition }\left({ }^{0} \mathrm{C}\right)\end{array}$} & Mean & \multicolumn{2}{|c|}{$\begin{array}{l}\text { Reducing sugars }(\%) \\
\text { Storage condition }\left({ }^{\circ} \mathrm{C}\right)\end{array}$} & Mean & \multicolumn{2}{|c|}{$\begin{array}{c}\text { Total sugars }(\%) \\
\text { Storage condition }\left({ }^{0} \mathrm{C}\right)\end{array}$} & Mean \\
\hline 0 & 42.00 & 42.000 & 42.000 & 5.500 & 5.500 & 5.500 & 39.680 & 39.680 & 39.680 \\
\hline 3 & 41.60 & 41.800 & 41.700 & 5.390 & 5.410 & 5.400 & 41.100 & 41.130 & 41.115 \\
\hline Mean & 41.60 & 41.767 & & 5.383 & 5.400 & & 41.687 & 41.710 & \\
\hline \multicolumn{10}{|c|}{$\mathrm{CD}(\geq 0.05)$ Storage intervals $(\mathrm{I})=0.033$ Storage conditions $(C)=\mathrm{NS} C \mathrm{x} \mathrm{I}=\mathrm{NS}$} \\
\hline
\end{tabular}

Table 6: Effect of storage temperature and interval on reducing sugars, total sugars (\%) and vitamin C of fermented carrot appetizer.

ing storage period both under ambient as well as under refrigeration. In ambient condition, initially total sugar was $39.68 \%$ which increased to $44.28 \%$ after 6 months whereas during refrigerated condition the increase ranged from $39.68 \%$ to $44.32 \%$.The comparatively minor increase in total sugar can be attributed to hydrolysis of polysaccharides in the acidic condition of the product during storage. Similar results have also been reported earlier also [18].
The effect of storage temperature and interval on overall acceptability of fermented carrot appetizer has been summarized in table 8. There was decrease in overall acceptability score during storage. Fermented carrot based appetizer having initial overall acceptability score 8.355 was decreased to 7.990 after three months and finally to 7.505 after six months storage. Higher decrease was found under ambient conditions (7.847) as compared to refrigerated conditions (8.053). 
In brief, it can be stated that during the storage of the appetizer for six months, there was no drastic change but only slight changes in all the physico-chemical and sensory characteristics except $\mathrm{pH}$, reducing sugars and browning where significant changes had taken place. Overall, the changes during storage were very small and did not affect the acceptability.

\begin{tabular}{|c|c|c|c|c|c|c|c|c|c|}
\hline \multirow{2}{*}{$\begin{array}{c}\text { Storage } \\
\text { intervals } \\
\text { (I) } \\
\text { Months }\end{array}$} & \multicolumn{2}{|c|}{$\begin{array}{l}\text { Vitamin } \mathrm{C} \\
\text { Storage condition }\left({ }^{0} \mathrm{C}\right)\end{array}$} & \multirow{2}{*}{ Mean } & \multicolumn{2}{|c|}{$\begin{array}{l}\text { Carotene }(\mathrm{mg} / 100 \mathrm{~g}) \\
\text { Storage condition }\left({ }^{0} \mathrm{C}\right)\end{array}$} & \multirow{2}{*}{ Mean } & \multicolumn{2}{|c|}{$\begin{array}{l}\text { Browning (OD at } 440 \mathrm{~nm} \text { ) } \\
\text { Storage condition }\left({ }^{\circ} \mathrm{C}\right)\end{array}$} & \multirow{2}{*}{ Mean } \\
\hline & Ambient & Refrigerated & & Ambient & Refrigerated & & Ambient & Refrigerated & \\
\hline 0 & 16.120 & 16.120 & 16.120 & 4.033 & 4.030 & 4.032 & 0.262 & 0.262 & 0.262 \\
\hline 3 & 14.967 & 15.057 & 15.012 & 3.860 & 3.890 & 3.875 & 0.269 & 0.265 & 0.267 \\
\hline 6 & 14.123 & 14.147 & 14.135 & 3.710 & 3.740 & 3.725 & 0.276 & 0.272 & 0.274 \\
\hline Mean & 15.070 & 15.108 & & 3.868 & 3.887 & & 0.269 & 0.266 & \\
\hline \multicolumn{10}{|c|}{$\begin{array}{l}\mathrm{CD}(\geq 0.05) \text { Storage intervals }(\mathrm{I})=0.033 \text { Storage conditions }(\mathrm{C})=\mathrm{NS} \mathrm{C} \times \mathrm{I}=\mathrm{NS} \\
\mathrm{AT}=\text { Ambient temperature }\left(13-27^{\circ} \mathrm{C}\right) ; \mathrm{RT}=\text { Refrigerated temperature }\left(0-4^{\circ} \mathrm{C}\right)\end{array}$} \\
\hline
\end{tabular}

Table 7: Effect of storage temperature and interval on vitamin, carotene and browning of fermented carrot appetizer.

\begin{tabular}{|c|c|c|c|c|c|c|}
\hline \multirow{2}{*}{$\begin{array}{c}\text { Storage } \\
\text { intervals (I) } \\
\text { Months }\end{array}$} & \multicolumn{2}{|c|}{ Storage condition (C) } & \multirow{2}{*}{ Mean } & \multicolumn{2}{|c|}{ Storage condition (C) } & \multirow{2}{*}{ Mean } \\
\hline & Ambient & Refrigerated & & Ambient & Refrigerated & \\
\hline 0 & 8.400 & 8.400 & 8.400 & 8.400 & 8.360 & 8.355 \\
\hline 3 & 7.800 & 8.190 & 7.995 & 7.995 & 8.100 & 7.990 \\
\hline 6 & 7.600 & 7.540 & 7.570 & 7.310 & 7.700 & 7.505 \\
\hline Mean & 7.933 & 8.043 & & 7.847 & 8.053 & \\
\hline
\end{tabular}

Table 8: Effect of storage temperature and interval on taste and overall quality of fermented carrot appetizer.

\section{Conclusion}

It is concluded that lactic acid fermented pulp can be successfully utilized for the preparation of different products. For highest sensory characteristics treatment (50\% fermented pulp + $50 \%$ unfermented pulp) as per the recipe in carrot gave the highest scores. During the passage of storage period, there was a slight decrease in all the physico-chemical and sensory characteristics except $\mathrm{pH}$ and browning. Thus, the developed technology can be commercially explored at industry level for production of the fermented processed products with probiotic effect. 


\section{Bibliography}

1. Block G. "Nutrient source of pro-vitamin A carotenoids in American diet". American Journal of Epidemiology 139 (1994): 290-293.

2. Joshi V K and Thakur S. "Lactic acid fermented beverages". In: Postharvest Technology of fruits and Vegetables. L R Verma and V K Joshi (eds.) Vol. II. Indus Publ. New Delhi (2000): 1102.

3. Hansen S L., et al. "Bioactivity of fat carinol and the influence of processing and storage on its content in carrots (Daucus carota L.)". Journal of Science of Food and Agriculture 83 (2003): 1010-1017.

4. Kidmose U., et al. Effects of genotypes, root size, storage and processing on Kidmose U, Hansen S L, Christensen P, Edilenbos M, Laesen M and Norback R (2004).

5. Frazier WC and Westhoff DC. Food microbiology. 7th edn. New Delhi: Tata McGraw Hill (1998): 352-359.

6. Joshi VK and Sharma S. "Lactic acid fermentation of radish for self stability and pickling". Natural Product Radiance 8.1 (2009): 19-24.

7. Joshi V K., et al. "Lactic Acid Fermentation of Food: A Potential Tool for Biopreservation and Product Development. Abstract". In: National seminar on Emerging Trends in Food Science and technology (2011a): 44.

8. Desai PD and Sheth T. "Controlled fermentation of vegetables using mixed inoculum of lactic cultures". Journal of Food Science and Technology 34 (1997): 155-158.

9. Sharma S. and Joshi VK. "Effect of temperature, salt concentration and type of microorganism on lactic acid fermentation of radish". Journal of Food Science and Technology 44 (2007): 611-614.

10. Joshi VK., et al. "Effect of temperature, salt concentration and type of microorganism on lactic acid fermentation of carrot". Acta Alimentaria 37 (2008): 205-219.

11. Sharma S., et al. "Lactic acid fermented foods". In: Food Biotechnology: Principles and Practices. Joshi, V.K. and Singh, R.S. (Eds). IK International Publishing House. New Delhi (2011):
375-415.

12. Joshi V K., et al. "Application of response surface methodology in optimization of lactic acid fermentation of radish: effect of addition of salt, additives and growth stimulators". Journal of Food Science and Technology (2014).

13. Leech H. "Lactic acid fermented foods and their benefits in Asia”. Food Control 8 (1997): 259-269.

14. Joshi V K., et al. "Production, purification, stability and efficacy of bacteriocin from isolates of natural lactic acid fermentation of vegetables". Food Technology and Biotechnology 44.3 (2006): 435-439.

15. Sharma S and Joshi VK. "Effect of Addition of Additives on Sequential Culture Lactic Acid Fermentation of Radish". International Journal of Food and Fermentation Technology 9.2 (2019): 133-138.

16. Joshi VK., et al. "Lactic acid fermentation of mushroom (Agaricus bisporus) for preservation and preparation of sauce". Acta Alimentaria 25 (1996): 1-11.

17. Joshi V K and Sharma S. "Preparation and evaluation of sauces from lactic acid fermented vegetables". Journal of Food Science and Technology 47.2 (2010): 214-218.

18. Joshi V K., et al. "Preparation and evaluation of appetizers from lactic acid fermented vegetables". Journal of Hill Agriculture 2.1 (2011): 20-27.

19. Karovicova J., et al. Chemical Papers. 56 (2002): 267.

20. Verma L R and Joshi V K. "Postharvest Technology of fruits and Vegetables”. Indus Publ. New Delhi (2000).

21. A.O.A.C. Official Methods of Analysis. Association of Official Analytical Chemists, W. Hortwitz (ed.). 13th edn. Washington DC (1980).

22. Ranganna S. "Handbook of analysis and quality control for fruit and vegetable products". 2nd edn. Tata McGraw Hill Publ Co. New Delhi (1986).

23. Joshi VK. "Sensory Science: Principles and applications in food evaluation". Agrotech Publishing Academy; Udaipur (2006). 
24. O’Mohony M. “Sensory Evaluation of Foods - Statistical Method and Procedures”. Marcel Dekker Inc., New York (1985).

25. Vaidya D and Vaidya M. "Fruit Juices and Juice beverages". In: Verma, L.R., Joshi,V.K. (Eds.), Post Harvest Technology of Fruits and Vegetables. Indus Publishing Company, New Delhi (2000): 708-709.

26. FASSI. Govt of India, FAD, Kotla Road, New Delhi (2006).

\section{Assets from publication with us}

- Prompt Acknowledgement after receiving the article

- Thorough Double blinded peer review

- Rapid Publication

- Issue of Publication Certificate

- High visibility of your Published work

Website: www.actascientific.com/

Submit Article: www.actascientific.com/submission.php

Email us: editor@actascientific.com

Contact us: +919182824667 